\title{
GERMINATION INDICES AND ANTIOXIDANT ACTIVITY ENZYME RESPONSES OF MADAGASCAR PERIWINKLE (CATHARANTHUS ROSEUS (L.) G. DON) UNDER PRE- TREATMENT BY SALICYLIC ACID
}

\author{
ABABAF, M. $^{1}$ - OMIDI, H. ${ }^{1}-$ BAKHSHANDEH, A. M. $^{2}$ \\ ${ }^{1}$ Agronomy and Plant Breeding Department, Agriculture Faculty, Shahed University \\ Tehran, Iran \\ (e-mail:m.ababaf@gmail.com; phone: +98-916-778-3620) \\ ${ }^{2}$ Agronomy and Plant Breeding Department, Agriculture Faculty, Ramin University of \\ Agriculture and Natural Resources, Mollasani, Iran \\ (e-mail: bakhshandeh50@yahoo.com; phone: +98-912-271-6580) \\ (Received $11^{\text {th }}$ Nov 2018; accepted $11^{\text {th }}$ Jan 2019)
}

\begin{abstract}
The present factorial experiment was conducted based on completely randomized design (CRD) with three replications in order to determine the optimum time and concentration for Catharanthus roseus seed priming with salicylic acid. Treatments included five different levels of salicylic acid $(0 ; 0.01 ; 0.1 ; 0.5$ and $1 \mathrm{mM})$ as well as five different periods of time $(0,6,12,24$, and 48 hours). Results indicated that the effects of concentration and time of priming were significant on all the studied traits. In addition, the effect of the interaction between concentration and priming time was significant on the mean time of germination, seedling length vigor index, chlorophyll content, and the activity of antioxidant enzymes. Further, the germination percentage increased by $24.1 \%$ and $22.3 \%$ in the treatment of $1 \mathrm{mM}$, and 48 hours, respectively, compared to the control. The highest germination speed was in $1 \mathrm{mM}$ and 48 -hour treatment, which had a $40 \%$ higher increase than the control. The interaction effect on the antioxidant activity indicated seed priming with $1 \mathrm{mM}$ concentration in 24 hours, leading to $84 \%$ and $62.6 \%$ increment in the catalase (CAT) and peroxidase (POD) activities, respectively, compared to the control. Furthermore, $0.1 \mathrm{mM}$ concentration in 24 hours led to $61.2 \%$ and $66.2 \%$ increment in chlorophyll a and total chlorophyll, respectively.
\end{abstract}

Keywords: catalase and peroxidase enzymes; photosynthetic parameters; phytohormone; seed priming

\section{Introduction}

Catharanthus is regarded as a medicinal ornamental plant. Catharanthus roseus is a perennial plant, semi-shrub or herbaceous and is related to the Apocynaceae family (Nejat et al., 2015). This plant is indigenous to Madagascar but is now widely distributed, and cultivated in China, India, Indonesia, Australia, North, and South America (Yang et al., 2011) (Verma et al., 2012). Catharanthus is known for its anti-cancer, anti-hypertensive, anti-diabetes, and antimicrobial properties. This plant contains about 130 bioactive Terpenoid Indole Alkaloids (TIAs), among which vinblastine and vincristine are regarded as the most important (Nejat et al., 2015). Catharanthus has a fairly long vegetative period due to its slow initial growth. It takes 180-200 days from cultivation to the maturity of the seed. (Omidbegi, 2006). The long growth period of the plant is considered as one of the limitations of its cultivation on a larger scale (Muthulakshmi and Pandiyarajan, 2013).

The process of germination of non-dormant seeds occurs in three phases including (I) imbibition, (II) lag phase, (III) the protrusion of the radicle through the testa (Bewley et al., 2013; Rosental et al., 2014). The duration of the third phase has great importance because the germination is completed and the embryo begins to develop concurrently during this period. Rapid seed germination and stand establishment are critical factors 
affecting crop production. After expanding our understanding of the processes involved in the germination methods used for changing the aforementioned factors, development of agriculturally applicable seeds began. The most frequently used method is known as "seed priming" (Bewley et al., 2013; Paparella et al., 2015). Seed priming is a controlled hydration technique which initiates the pre-germination metabolisms without actual germination (Hussain et al., 2015). In addition, it is considered as one of the most effective, pragmatic and short-term approaches to improve seed vigor (Batool et al., 2015), rate and percentage of seed germination (Santini and Martorell, 2013) synchronization of germination, crop establishment (Pouramir-Dashtmian et al., 2014; Paparella et al., 2015) and the seedling growth of many crops (Farooq et al., 2009) Further, it is associated with a wide range of metabolic and physiological improvements (Shehab et al., 2010) and cellular and molecular changes (Siri et al., 2013).

When the primed seeds are sown, the imbibition phase and lag phase of water absorption are shortened (Khan et al., 2009) to reduce growth time, in order to increase the productivity of agricultural land in such a way that the reported Indian farmers could harvest three products in one year (Harris et al., 2001).

The induced priming increase in the rate of seed germination was associated with the initiation of germination related processes, repair processes and increased levels of various free radical scavenging enzymes such as superoxide dismutase (SOD), CAT and POD (Vazirimehr et al., 2014). Furthermore, the positive effects of priming on seed germination in various species of plants are related to inducing biochemical mechanisms, repairing, and rebuilding cells (Di Girolamo and Barbanti, 2012) by activating the synthesis of many proteins and enzymes involved in cell metabolism (Varier et al., 2010). Salicylic acid (SA) is a phenolic compound, known as "phytohormone", which contributes to the regulation of the growth and development processes, especially seed germination, photosynthesis, respiration, flowering, and senescence (Rivas-San Vicente and Plasencia, 2011). Some studies indicated that priming strategies can enhance the activities of free radical scavenging enzymes such as CAT, POD, and SOD (Sharma et al., 2014). These enzymes reduce lipid peroxidation at the germination stage and increase the percentage and rate of germination (Baalbaki et al., 1999).

Recently, it has been reported that there are some encoding antioxidant enzymes such as CAT, SOD, and Ascorbate peroxidase (APX) preventing the overproduction of reactive oxygen species (ROS) among genes stimulated by SA (El-Esawi et al., 2017), Moreover, SA may act directly as an antioxidant, scavenging ROS (Popova et al., 2009). The utility of SA in inducing the plant defense mechanisms depends on its concentration and the method of its application (Huang et al., 2016). Hussein (2015) evaluated the effect of seed priming with SA $(100 \mathrm{mg} / \mathrm{L})$ for four hours at $25^{\circ} \mathrm{C}$ on the germination of okra (Abelmoschus esculentus L.). The result indicated that seed priming with SA can induce the highest germination percentage and seed vigor index. Based on the results of previous studies, the effect of the interaction between time and different priming concentrations with gibberellic acid and SA was significant on germination rate (Azarniya et al., 2016).

There are many factors related to the effects of seed priming, which depend on the concentrations of priming solutions, the time and the temperature during priming (Khan, 1992). Thus, the optimization of the priming technique is important to achieve the best results (Maiti and Pramanik, 2013). Regarding the long growth period of this plant, the small size of the seed and poor establishment in the field with semi-heavy and heavy textured soils, the present study aimed to evaluate the effect of seed priming with SA in 
different concentrations and periods of time on improving Catharanthus roseus seed germination indexes.

\section{Materials and methods}

\section{Preparation, Priming of seeds and germination process}

The present study was conducted in order to assess the priming effects of time and various concentrations of SA on germination parameters, Catharanthus seed (Photo 1), with a factorial experiment based on completely randomized design (CRD) with three replications at the Laboratory of Seed Science and Technology of Shahed University in Tehran. Treatments included five different concentrations of SA $(0,0.01,0.1,0.5$ and 1 $\mathrm{mM})$ and five periods of time (0, 6, 12, 24 and 48 hours). The seeds were purchased from the company named Green Farm, and were surface-sterilized using $70 \%$ ethanol for 30 seconds, washed with distilled water three times, transferred to a solution of 50\% Clorox (containing $5.25 \% \mathrm{NaOCl}$ ) for $15 \mathrm{~min}$, and were finally rinsed three times with sterile distilled water (Taha et al., 2009). The seeds were placed in SA solutions with different concentrations, and for different times $\left(6,12,24\right.$, and 48 hours) at $25{ }^{\circ} \mathrm{C}$ in darkness (Pandey, 2017). After removing the priming solution with distilled water, seeds were redried to the initial moisture content (Ratikanta, 2011) at $25^{\circ} \mathrm{C}$ for 24 hours in the laboratory. In every sterilized Petri dish ( $90 \mathrm{~mm}$ diameter), 50 seeds were sowed with two-layer Whatman filter papers moistened with $5 \mathrm{ml}$ appropriate solutions. Thus, untreated seeds were used as control. In order to prevent water evaporation, the Petri dishes were closed with parafilm and placed in a germinator at $25 \pm 1{ }^{\circ} \mathrm{C}$ (Prabhu and Rajeswari, 2017) with a photoperiod of 12/12 h day/night light (Senbagalakshmi et al., 2017). The germinated seeds with a root length longer than $2 \mathrm{~mm}$ were counted (LiopaTsakalidi et al., 2012).

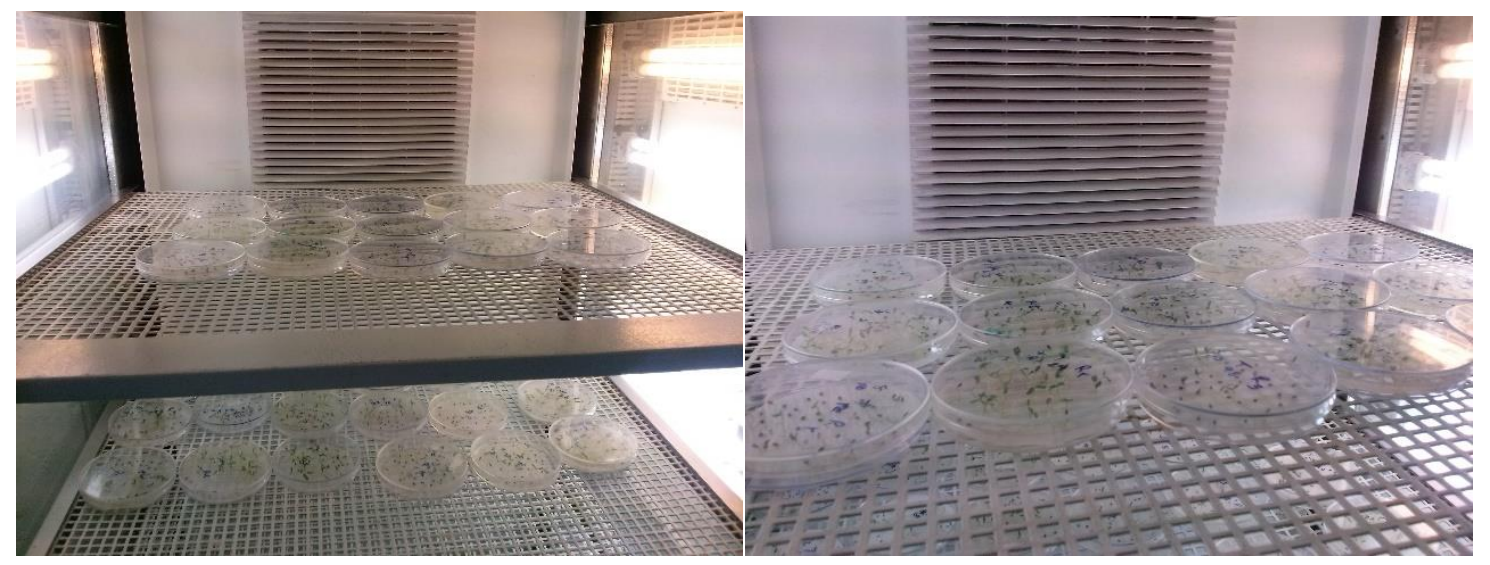

Photo 1. Catharanthus seed germination in a germinator at the laboratory

Each day germinated seeds that had a root length over $2 \mathrm{~mm}$ were counted (Kaya et al., 2006). At the end of the experiment (10 days) (Barkat et al., 2017) five samples were randomly selected from each petri dish (Huang and Redmann, 1995) and seedling length, plumule length, radicle length, seedling dry weight (Panwar and Bhardwaj, 2005) (LiopaTsakalidi et al., 2012), mean germination time (Ranal and Santana, 2006), mean daily germination (Hunter et al., 1984), seedling length vigor index and seedling weight vigor 
index (Hu et al., 2005) were calculated according to the following equations (Eq.1-5) (Hunter et al., 1984):

$$
\begin{gathered}
\text { Germination percentage }(G P)=(N \times 100) / M \\
\text { Mean germination time }(M G T)=\stackrel{a}{ }(N i D i) / \stackrel{a}{N} \\
\text { Mean daily germination }(M D G)=G P / T
\end{gathered}
$$

Seedling length vigor index $=$ Germination percentage $\times$ Seedling length (Eq.4)

Seedlingweightvigor index $=$ Germination percentage $\times$ Seedling dry weight (Eq.5)

$\mathrm{N}$ : the sum of germinated seeds at the end of the experiment, $\mathrm{M}$ : the total number of planted seeds, Di: The time from the start of the experiment to the $\mathrm{i}^{\text {th }}$ observation, $\mathrm{Ni}$ : the number of germinated seeds at time $\mathrm{Di}, \Sigma \mathrm{N}$ : Total germinated seeds at the end of experiment, T: Period of germination.

\section{Antioxidant enzymes assay}

An enzyme extract was prepared by the method of Mukherjee and Choudhuri (1983). A 0.5 gr leaf sample was homogenized in $10 \mathrm{ml}$ of $100 \mathrm{mM}$ phosphate buffer $\left(\mathrm{KH}_{2} \mathrm{PO}_{4} / \mathrm{K}_{2} \mathrm{HPO}_{4}\right) \mathrm{pH} 7.0$, containing $1 \%(\mathrm{w} / \mathrm{v})$ insoluble polyvinylpyrrolidone (PVP). The homogenate was centrifuged at $\mathrm{x} 15,000 \mathrm{~g}$ for $10 \mathrm{~min}$ at $4{ }^{\circ} \mathrm{C}$, and the resulting supernatant was collected and stored at $4{ }^{\circ} \mathrm{C}$ for CAT, POD assays.

\section{Peroxidase assay}

The POD activity was assayed following the method of Gueta-Dahan et al., (1997). The reaction mixture contained, $50 \mathrm{mM}$ potassium phosphate buffer $(\mathrm{pH} 7.0), 1 \%$ guaiacol, $1 \% \mathrm{H}_{2} \mathrm{O}_{2}$, and $0.3 \mathrm{ml}$ enzyme extract. The change of absorption due to guaiacol oxidation were recorded at $470 \mathrm{~nm}$ for 3 min per $15 \mathrm{~s}$ with spectrophotometer. In the next procedure, the enzyme activity was calculated using the extinction coefficient of tetraguaiacol $\left(26.60 \mathrm{mM}^{-1} \mathrm{~cm}^{-1}\right.$ extinction coefficient).

\section{Catalase assay}

Catalase activity was determined using the method of Chaoui et al., (1997). The reaction mixture consisted of $125 \mathrm{mM}$ potassium phosphate buffer $(\mathrm{pH} 7.0)$ and $100 \mathrm{mM}$ $\mathrm{H}_{2} \mathrm{O}_{2}$, and $25 \mu \mathrm{L}$ of the enzyme extract in a total volume of $3 \mathrm{~mL}$. The absorbance at 240 $\mathrm{nm}$ for $1 \mathrm{~min}$ at $25^{\circ} \mathrm{C}$ was recorded spectrophotometrically. The enzyme activity was expressed in $\triangle \mathrm{OD} \mathrm{g}{ }^{-1} \mathrm{FW} \mathrm{min}^{-1}$.

\section{Chlorophylls and carotenoid content}

$0.5 \mathrm{~g}$ of fresh leaf tissues were ground in $5 \mathrm{ml}$ of $80 \%(\mathrm{v} / \mathrm{v})$ acetone using mortar and pestle. The suspension was centrifuged at $6,000 \mathrm{~g}$ for $10 \mathrm{~min}$ at $4^{\circ} \mathrm{C}$. Absorbance of the solution was then measured at 645 and 663 for chlorophylls and at 470 for carotenoids. 
The chlorophyll and carotenoid contents were determined using the formula given by Arnon (1967), and the following formulas (Eq.6-9):

$$
\begin{aligned}
& \text { Chlorophyll a }(\mathrm{mg} / \mathrm{gr} \text { fresh weight })=\left[19.3\left(A_{663}\right)-0.86\left(A_{645}\right)\right] v / 100 w \quad \text { (Eq.6) } \\
& \text { Chlorophyll } b(\mathrm{mg} / \mathrm{gr} \text { fresh weight })=\left[19.3\left(A_{645}\right)-3.6\left(A_{663}\right)\right] v / 100 w \text { (Eq.7) } \\
& \text { Total chlorophyll }(\mathrm{mg} / \text { gr fresh weight })=\left[20.8\left(A_{645}\right)+8.02\left(A_{663}\right)\right] v / 100 w \text { (Eq.8) } \\
& \text { Carotenoids }=\left[\left(100\left(A_{470}\right)-3.27(\text { mgchl } a)-104(\text { mgchl } b)\right] / 227\right. \text { (Eq.9) }
\end{aligned}
$$

$A=$ absorption of light at wavelengths of 663,645 and $470 \mathrm{~nm}$

$\mathrm{V}=$ the volume upper solution of centrifuges

$\mathrm{W}=$ weight of the sample in grams

\section{Statistical analysis}

After normalization test (Kolmogorov-Smirnov and ShapiroWilk test), the data were analyzed with SAS 9.1 (SAS Institute, Cary, NC, USA). Means were compared with Duncan's multiple range tests in SAS at 5\% statistical probability levels. The graphs were drawn with MS-Excel.

\section{Results}

\section{Germination percentage}

According to the analysis of variance (Table 1), the effect of duration and concentration of seed priming on germination percentage was significant at $\mathrm{P} \leq 0.01$. However, the interaction between duration and concentration of seed priming failed to have a significant impact on germination percentage (Table 1). The comparison of the mean of results indicated that by increasing the duration of priming, germination percentage also becomes higher (Table 3 ). In addition, the highest germination percentage (83.2\%) was shown in the 24 hour treatment, while the lowest germination percentage $(64.6 \%)$ in control (Table 3). Further, the highest germination percentage was detected in $1 \mathrm{mM}$ SA indicating a $24.1 \%$ increase, compared to the control, which allocated the lowest amount (control= nonprimed) $($ Table 3$)$.

\section{Mean germination time and mean of daily germination}

Based on the results of ANOVA (Table 1), priming duration and concentration had a significant impact on mean germination time and mean of daily germination. Furthermore, the interaction effect between treatments has a significant influence on mean germination time at $\mathrm{p} \leq 0.05$ (Table 1). The results of mean comparison showed that the highest mean germination time (4.5 days) was in the case of the control while treatment $0.01 \mathrm{mM} \mathrm{SA}+48 \mathrm{~h}$ hours with mean germination 2.7 days had the fastest germination (Fig. 1). The mean seed germination time is considered a very important trait in planting establishment and exploiting environmental conditions. 
Table 1. Analysis of variance effect of timing and concentration priming with salicylic acid on Catharanthus roseus seed germination indexes

\begin{tabular}{|c|c|c|c|c|c|c|c|c|c|}
\hline \multicolumn{10}{|c|}{ Mean square } \\
\hline S.O.V & df & $\begin{array}{c}\text { Germination } \\
\text { percentage }\end{array}$ & $\begin{array}{c}\text { Mean } \\
\text { germination } \\
\text { time }\end{array}$ & $\begin{array}{l}\text { Mean of daily } \\
\text { germination }\end{array}$ & $\begin{array}{c}\text { Seedling } \\
\text { length }\end{array}$ & $\begin{array}{c}\text { Plumule } \\
\text { length }\end{array}$ & $\begin{array}{l}\text { Radicle } \\
\text { length }\end{array}$ & $\begin{array}{c}\text { Seedling } \\
\text { weight vigor } \\
\text { index }\end{array}$ & $\begin{array}{c}\text { Seedling } \\
\text { length } \\
\text { vigor index }\end{array}$ \\
\hline Concentration & 4 & $1045.07^{* *}$ & $2.64 * *$ & $12.89 * *$ & $1.26^{*}$ & $0.07^{\mathrm{n} . \mathrm{s}}$ & $0.84^{\text {n.s }}$ & $3422.03 * *$ & $26028.51 * *$ \\
\hline Time & 4 & $904.13^{* *}$ & $2.97 * *$ & $11.15^{* *}$ & $1.59^{* *}$ & $0.16^{*}$ & $1.38^{*}$ & $1135.96^{* *}$ & $13174.6^{* *}$ \\
\hline $\begin{array}{c}\text { Concentration } \times \\
\text { time }\end{array}$ & 16 & $105.03^{\text {n.s }}$ & $0.33^{*}$ & $1.3^{\mathrm{n} . \mathrm{s}}$ & $0.37^{\mathrm{n} . \mathrm{s}}$ & $0.03^{\text {n.s }}$ & $0.39^{\text {n.s }}$ & $269.28^{\mathrm{n} . \mathrm{s}}$ & $3863.39 *$ \\
\hline $\begin{array}{c}\text { Experimental } \\
\text { error }\end{array}$ & 50 & 110.50 & 0.14 & 1.36 & 0.35 & 0.04 & 0.49 & 225.58 & 1987.32 \\
\hline $\begin{array}{l}\text { Coefficient of } \\
\text { variation }(\%)\end{array}$ & - & 13.88 & 9.72 & 13.87 & 14.00 & 11.63 & 28.48 & 21.49 & 14.01 \\
\hline
\end{tabular}

$\mathrm{ns}, *$ and $* *$ : non-significant, significant at 5 and $1 \%$, respectively

Table 2. Analysis of variance effect of timing and concentration priming with salicylic acid on Catharanthus roseus

\begin{tabular}{|c|c|c|c|c|c|c|c|}
\hline \multicolumn{8}{|c|}{ Mean square } \\
\hline S.O.V & df & CAT & POD & Chl a & Chl b & Total Chl & Carotenoide \\
\hline Concentration & 4 & $35.69 * *$ & $43.55 * *$ & $4.7 * *$ & $0.30 * *$ & $4.67 * *$ & $0.25 * *$ \\
\hline Time & 4 & $77.62 * *$ & $23.52 * *$ & $2.43 * *$ & $0.24 * *$ & $3.26 * *$ & $0.19 * *$ \\
\hline Concentration $\times$ time & 16 & $8.76^{* *}$ & $6.2 * *$ & $0.44 * *$ & $0.02 * *$ & $0.41 * *$ & $0.02 * *$ \\
\hline Experimental error & 50 & 1.64 & 1.15 & 0.013 & 0.001 & 0.002 & 0.0007 \\
\hline Coefficient of variation (\%) & - & 29.63 & 14.80 & 2.99 & 7.12 & 1.12 & 4.7 \\
\hline
\end{tabular}

ns, $*$ and $* *$ : non-significant, significant at 5 and $1 \%$, respectively

Chl: Chlorophyll; CAT: catalase activity; POD: peroxidase activity 
Table 3. Mean comparison of the effects of concentration and priming time on germination characteristics

\begin{tabular}{|c|c|c|c|c|c|c|}
\hline Characteristics & $\begin{array}{c}\text { Germination } \\
\text { percentage } \\
(\%)\end{array}$ & $\begin{array}{c}\text { Mean of } \\
\text { daily } \\
\text { germination } \\
\text { (day) }\end{array}$ & $\begin{array}{l}\text { Seedling } \\
\text { length } \\
(\mathrm{cm})\end{array}$ & $\begin{array}{l}\text { Plumule } \\
\text { length } \\
(\mathrm{cm})\end{array}$ & $\begin{array}{l}\text { Radicle } \\
\text { length } \\
(\mathrm{cm})\end{array}$ & $\begin{array}{c}\text { Seedling } \\
\text { weight } \\
\text { vigor } \\
\text { index } \\
\end{array}$ \\
\hline \multicolumn{7}{|c|}{ Concentration SA (mM) } \\
\hline Control 0 & $64.66 \mathrm{c}$ & $7.18 \mathrm{c}$ & $4.55 \mathrm{a}$ & $1.77 \mathrm{ab}$ & $2.78 \mathrm{a}$ & $56.18 b$ \\
\hline 0.01 & $71.6 \mathrm{bc}$ & $7.95 \mathrm{bc}$ & $3.94 b$ & $1.73 b$ & $2.20 \mathrm{a}$ & $55.71 b$ \\
\hline 0.1 & $74.53 b$ & $8.28 b$ & $4.048 \mathrm{~b}$ & $1.75 \mathrm{ab}$ & $2.31 \mathrm{a}$ & $66.07 \mathrm{~b}$ \\
\hline 0.5 & $82.66 \mathrm{a}$ & $9.18 \mathrm{a}$ & $4.57 \mathrm{a}$ & $1.91 \mathrm{a}$ & $2.65 \mathrm{a}$ & $83.2 \mathrm{a}$ \\
\hline 1 & $85.2 \mathrm{a}$ & $9.46 \mathrm{a}$ & $4.18 \mathrm{ab}$ & $1.78 \mathrm{ab}$ & $2.44 \mathrm{a}$ & $88.06 \mathrm{a}$ \\
\hline \multicolumn{7}{|l|}{ Time (hour) } \\
\hline 0 & $64.66 \mathrm{c}$ & $7.18 \mathrm{c}$ & $4.55 \mathrm{a}$ & $1.77 \mathrm{~b}$ & $2.78 \mathrm{a}$ & $56.45 b$ \\
\hline 6 & $71.33 \mathrm{bc}$ & $7.92 \mathrm{bc}$ & $4.55 \mathrm{a}$ & $1.93 \mathrm{a}$ & $2.64 \mathrm{a}$ & 66.67ab \\
\hline 12 & 77.33ab & $8.59 \mathrm{ab}$ & $3.80 \mathrm{c}$ & $1.84 \mathrm{ab}$ & $2.00 \mathrm{~b}$ & $71.96 a$ \\
\hline 24 & $83.2 \mathrm{a}$ & $9.24 \mathrm{a}$ & $4.32 \mathrm{ab}$ & $1.72 b$ & $2.6 \mathrm{a}$ & $78.44 \mathrm{a}$ \\
\hline 48 & $82.13 \mathrm{a}$ & $9.12 \mathrm{a}$ & $4.05 b c$ & $1.67 \mathrm{~b}$ & $2.38 \mathrm{ab}$ & $75.77 \mathrm{a}$ \\
\hline
\end{tabular}

In each column, means sharing at least one letter, are not significantly different according to Duncan's multiple range test $(\mathrm{p} \leq 0.05)$

*SA: Salicylic acid

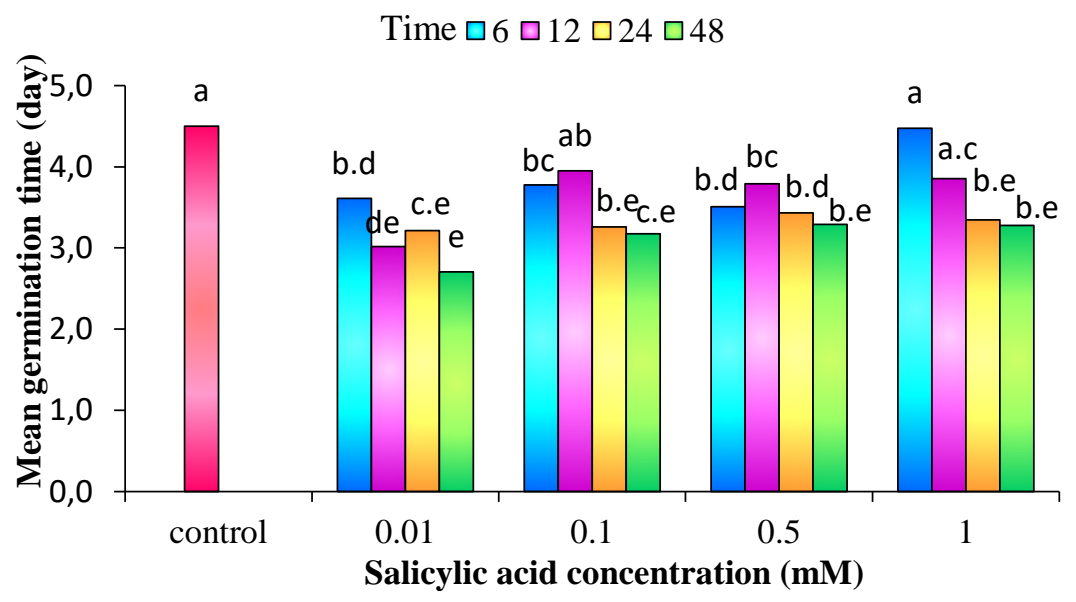

Figure 1. Mean comparison of the effect of time and concentration on mean germination time

The effect of different periods of time indicated that the highest and lowest required time for mean daily germination observed in the control and 24 hour long priming, were 9.2 and 7.1 days, respectively (Table 3). Furthermore, the speed of daily germination in the case of 24 hour treatment was $22.8 \%$ higher, compared to that of the control, although it was observed in the same statistical group with 12 and 48 hour treatments (Table 3). Results comparing the mean of the effect of different concentrations of SA showed, that increasing the concentration lead to a raise in mean daily germination and maximum mean daily germination achieved in $1 \mathrm{mM}$ concentration SA which it did not has a meaningful difference with $0.5 \mathrm{mM}$ concentration SA (Table 3). 


\section{Seedling length}

The results indicated that the main effects of priming time and concentration of SA played a significant effect on seedling length (Table 1). The highest and shortest seedling lengths were observed in 6 hour and 12 hour treatments, respectively (Table 3). The results showed that the maximum seedling length $(4.57 \mathrm{~cm})$ occurred in the $0.5 \mathrm{mM} \mathrm{SA}$ treatment and the lowest seedling length $(3.9 \mathrm{~cm})$ was found in the $0.01 \mathrm{mM}$ SA treatment (Table 3).

\section{Plumule length and radicle length}

The results of ANOVA revealed that priming at different times could significantly influence the plumule and radicle length at $\mathrm{P} \leq 0.05$, but the concentrations of SA had no significant effect on these characteristics (Table 1). In addition, 6 hour seed priming had the highest plumule length and a significant increase occurred in the control treatment (Table 3). The shortest radicle length $(2 \mathrm{~cm})$ occurred in the 12 hour treatment priming, and had a significant difference compared to other treatments (Table 3).

\section{Seedling weight and length vigor index}

The effect of concentration and time on seedling weight and length vigor index was significant at the significance level of $\mathrm{p} \leq 0.01$ (Table 1). In addition, the interaction between concentration $\times$ time on the seedling length vigor index was also significant (Table 1). The highest seedling length vigor index was observed during $1 \mathrm{mM} \mathrm{SA}+24$ hour priming (Fig. 2). Among the main effects of concentration and time priming, 24 hour treatment and $1 \mathrm{mM}$ SA concentration revealed the highest seedling weight vigor index (Table 3).

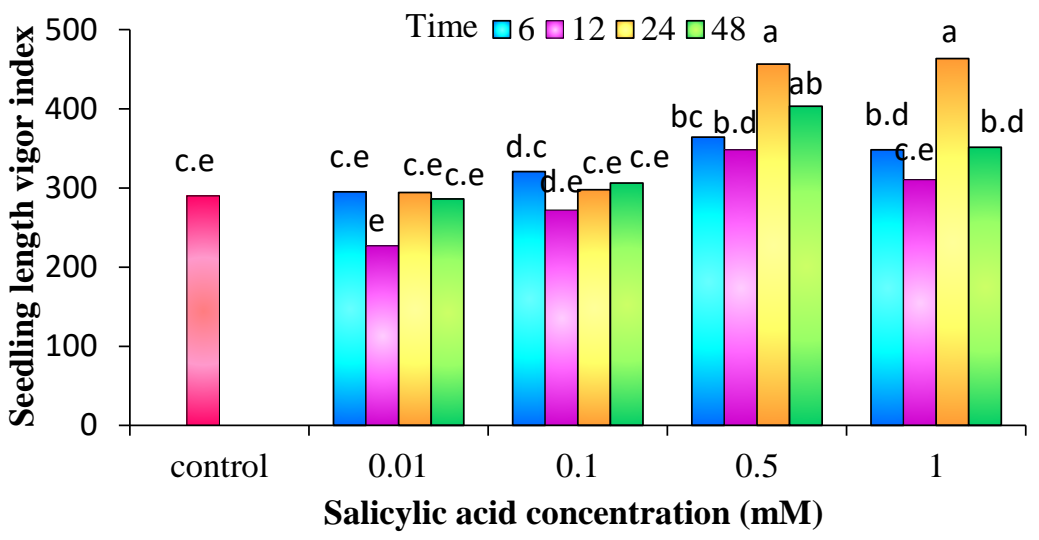

Figure 2. Mean comparison of the effect of time and concentration on seedling length vigor index

\section{Chlorophyll content and carotenoids}

According to the results, the effects of priming time and concentration, as well as interaction of concentration $\times$ time on chlorophyll a, b, total chlorophyll, and carotenoids were significant $(\mathrm{p} \leq 0.01)$ (Table 2). The highest chlorophyll $\mathrm{a}, \mathrm{b}$ and total chlorophyll contents were related to the concentration of $0.1 \mathrm{mM} \mathrm{SA}$, (Fig. 3, 4, 5) and higher carotenoid content was related to the treatment of $1 \mathrm{mM} \mathrm{SA}$ (Fig. 6). The results of this 
experiment showed that among the different levels of priming, 24 hours of treatment and control had the highest and lowest levels of chlorophyll a, total and carotenoids, respectively (Figs. 3, 5, 6).

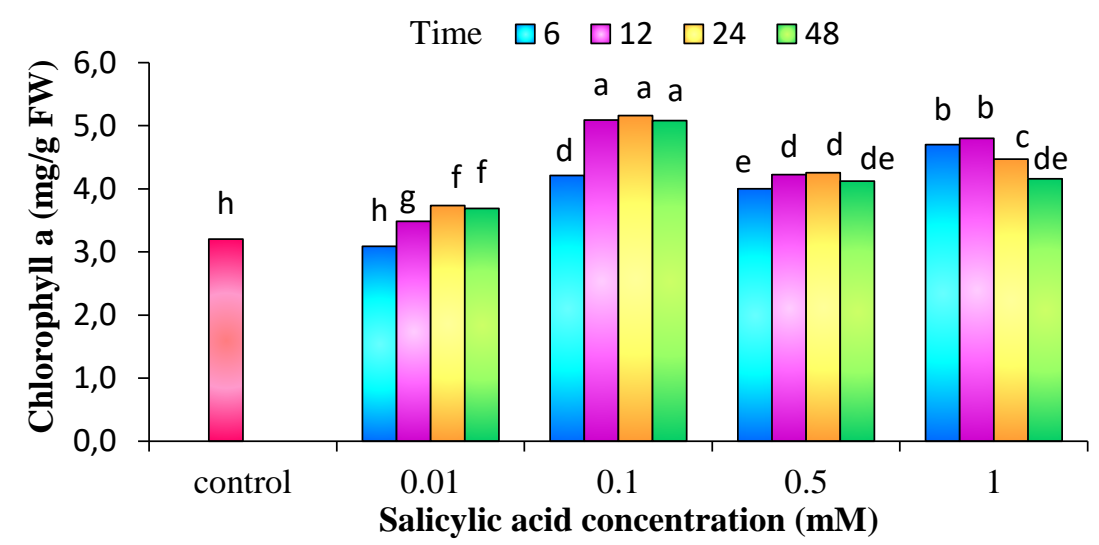

Figure 3. Mean comparison of the effect of time and concentration on chlorophyll a

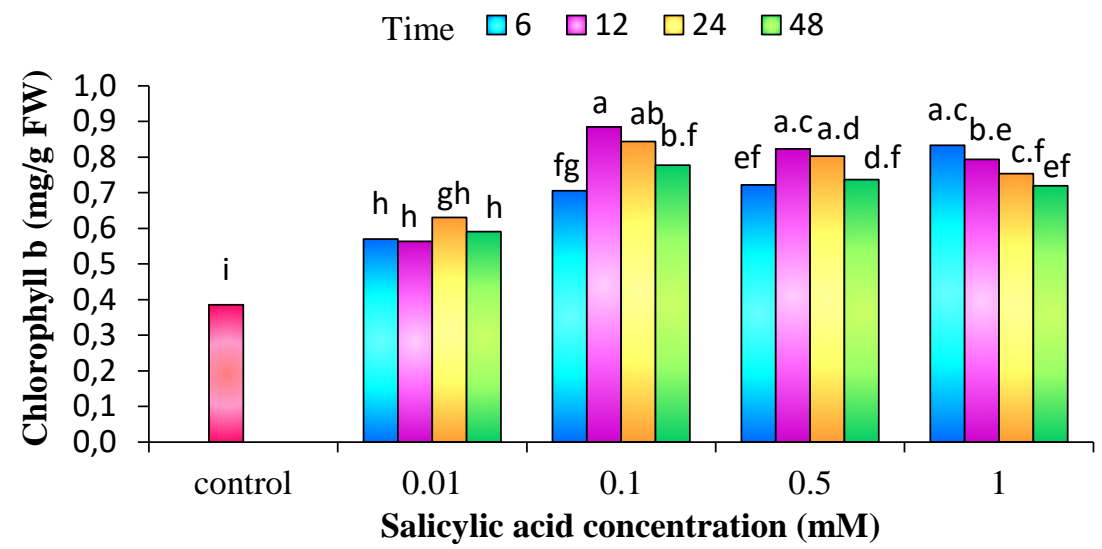

Figure 4. Mean comparison of the effect of time and concentration on chlorophyll $b$

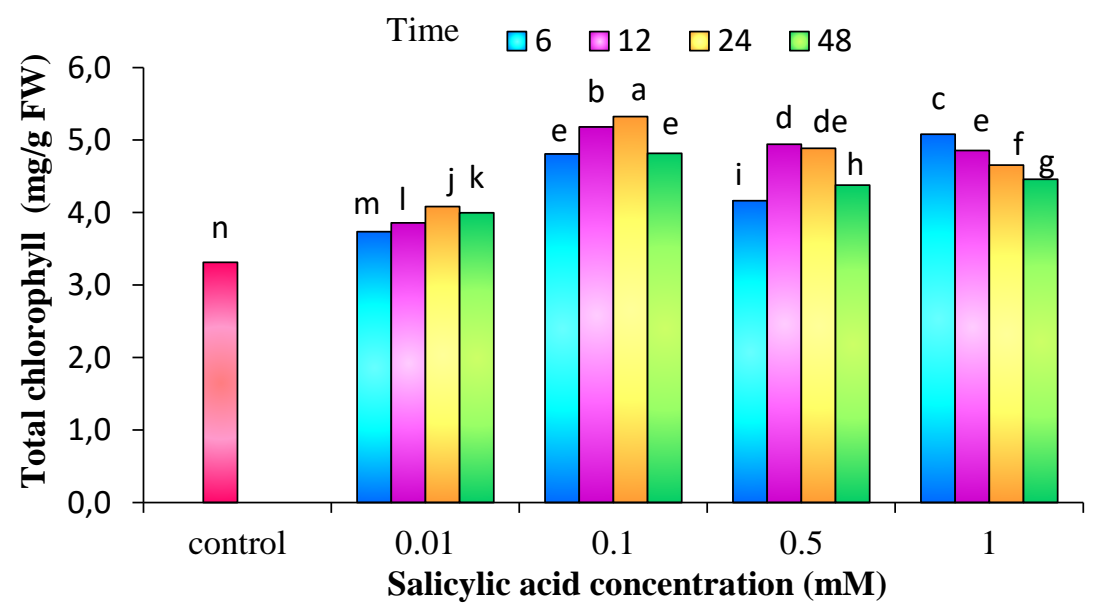

Figure 5. Mean comparison of the effect of time and concentration on Total chlorophyll 


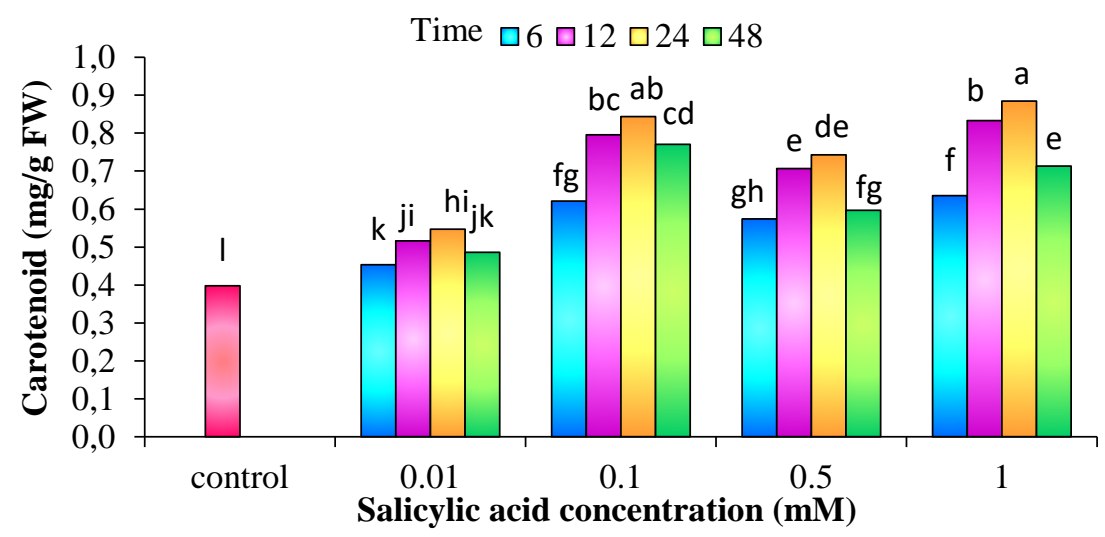

Figure 6. Mean comparison of the effect of time and concentration on carotenoid

Furthermore, the highest and lowest levels of chlorophyll $b$ were observed in the of 24 hour and control treatments (Fig. 4). In addition, interaction between concentration $\times$ time of priming indicated the highest concentration of chlorophyll a and total was at $0.1 \mathrm{mM}$ $\mathrm{SA}+24$ hour seed priming (Figs. 3, 5) and the highest content of chlorophyll b and carotenoids was at $0.1 \mathrm{mM} \mathrm{SA}+12$ hour and $1 \mathrm{mM} \mathrm{SA}+48$ hours of priming, respectively (Figs. 4, 6).

\section{Antioxidant enzymes activities}

The effects of time, concentration levels of priming, and the interaction between time $\times$ concentration on the activity of CAT and POD enzymes were significant at least at the significance level of $1 \%$ (Table 2). The highest activity of CAT enzyme was related to 1 mM SA treatment, which indicated a $84 \%$ higher activity than that of the control. Further, no significant difference was observed between the SA concentration of 0.1 and $1 \mathrm{mM}$ (Fig. 7). Among the different priming times, 24-hour treatment and control had the highest and lowest activity of antioxidant enzymes, respectively. Furthermore, the interaction effects of $1 \mathrm{mM} \mathrm{SA}+24$ hours had the most significant effect on the activity of CAT enzyme (Fig. 7).

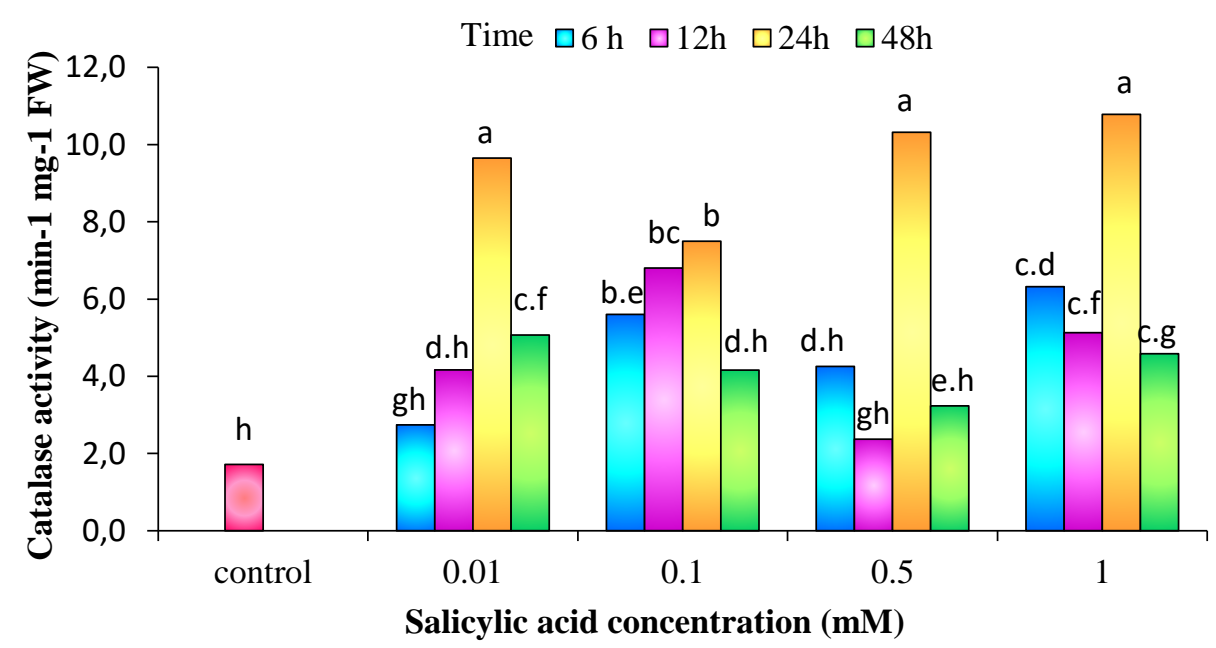

Figure 7. Mean comparison of the effect of time and concentration on catalase activity 
Based on ANOVA results, the highest POD enzyme activity was related to $1 \mathrm{mM}$ SA concentration and 12 hours of treatment (Fig. 8). In addition, the means of the comparison of the interaction between SA concentrations $\times$ time indicated higher POD enzyme activity when the seeds primed with $1 \mathrm{mM} \mathrm{SA}+24$ hours (Fig. 8).

Time $\square 6 \mathrm{~h} \square 12 \mathrm{~h} \quad \square 24 \mathrm{~h} \square 48 \mathrm{~h}$

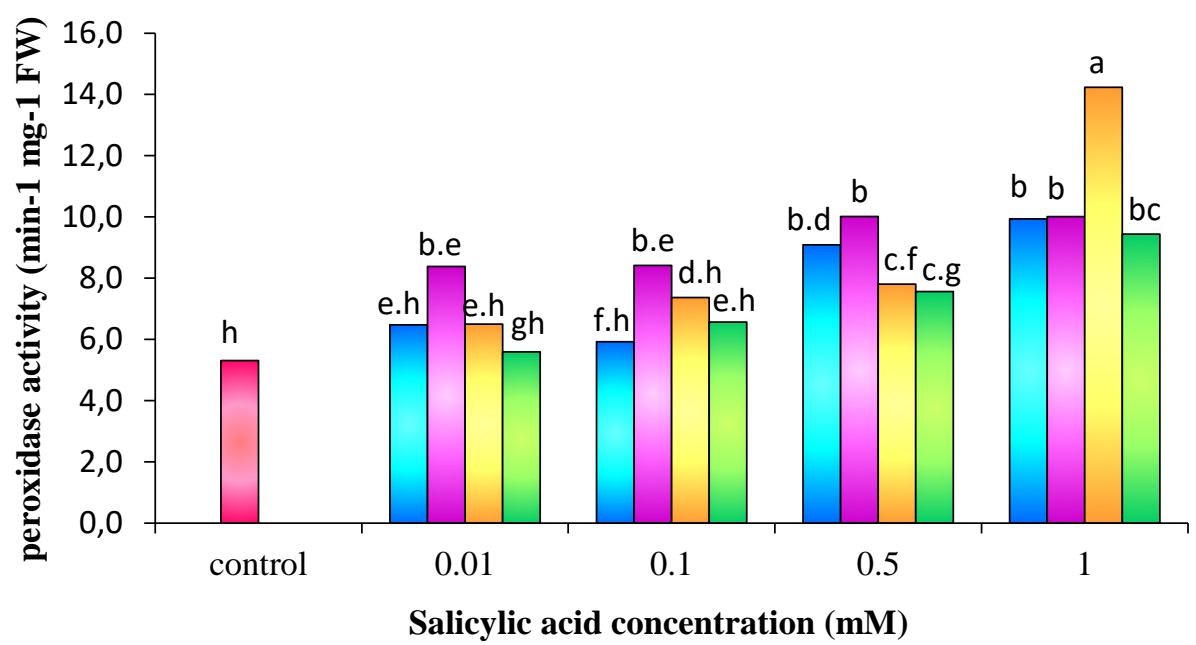

Figure 8. Mean comparison of the effect of time and concentration on peroxidase activity

\section{Discussion}

Several reports have been published demonstrating the role of SA in various physiological processes. Some of these reports demonstrated the protective or damaging effect of exogenous SA (Szalai et al., 2011). Priming pepper seeds in acetyl-SA improved the final germination percentage, and led to higher shoot and root dry weights (Korkmaz, 2005). However, it should also be noted that a dramatic inhibition of the germination process was reported above the concentration of $1 \mathrm{mM}$ in maize (Guan and Scandalios, 1995).

Results indicated that by increasing the SA concentration germination percentage also becomes higher (Table. 3). Gorzi et al. (2017) reported that the seed priming with SA improved the germination parameters and seedling growth of stevia. Furthermore, SA may stimulate the seed germination via biosynthesis of gibberellic acid and induce thermogenesis (Shah, 2003). Previous studies reported that isocitrate lyase and malate synthase were found to be more abundant in seeds germinated in the presence of SA than in its absence. Isocitrate lyase and malate synthase are two key enzymes of the glyoxylate cycle, which play a crucial role in synthesizing carbohydrates from storage lipids during seed germination and seedling establishment (Eastmond and Graham, 2001).

Khoramdel et al. (2012) reported that an increase in SA concentration from 0.1 to 1 $\mathrm{mM}$ leads to an increase in germination percentage, and a reduction of the germination percentage occurred after increasing the concentration. It seems that different effects may be observed in different concentrations since SA is considered as a plant growth regulator. The time of contact with these substances is very important, along with the use of plant hormones. Thus, the amount or concentration of hormones should be lower in long time periods and it is better to consider the higher concentration of growth regulator 
substances in shorter periods of time. By increasing the duration of priming, hormones can better penetrate into seeds, leading to an increase in the activity of germination stimulating enzymes, as well as the percentage and speed of seed germination (Azarniya et al., 2016). Shahverdi et al. (2017) reported the highest germination percentage among the priming duration and different concentrations of boric acid were observed under 24 hours of priming. Application of $0.01 \mathrm{mM}$ SA during a 48 hour priming showed the lowest mean seed germination time (Fig l).

Reducing the mean germination time due to seed priming is related to an increase in the rate of cell division in primed seeds because the synthesis of RNA, DNA, and protein were completed in many physiological stages and the seed was placed at the threshold germination during seed priming (Foti et al., 2008; Brancalion et al., 2008). The results of the present study indicated that the 6 hour seed priming treatment had the highest seedling length and plumule (Table. 3). Compared to non-primed seeds, an important feature of primed seeds is that they quickly germinate and produce radicle and plumule in optimal conditions. Thus, the seedling length of primed seeds is considerably higher than that of non-primed seeds (Murungu et al., 2003). The maximum seedling length was assessed during the $0.5 \mathrm{mM} \mathrm{SA}$ treatment. The results of this study are in line with previous studies that indicated applying SA was more effective by soaking the seeds, and the best results were obtained using $0.5 \mathrm{mM}$ SA solution (Baninasab, 2010). In addition, SA regulates elongation and cell division in collaboration with materials such as auxin. Furthermore, the exogenous application of SA causes cell division in the terminal meristem of the primary roots, which results in increasing longitudinal growth (Serraj and Sinclair, 2002).

Seedling length vigor index is derived from both multiplication germination percentage and seedling length. Therefore, every treatment increasing these two components leads to an increase in seed vigor. Thus, an increase in seed vigor using priming treatments can be related to increasing the activity of the enzymes involved in germination. Consequently, an increase in the consumption of seed reserves and length of seedling can be attributed to increased energy in primed seeds (Omid and Farzad, 2012). The results of our study indicated that 24 hours treatment and $1 \mathrm{mM}$, SA concentration resulted in the best seedling weight vigor index and seedling length vigor index (Table. 3).

Azarniya et al. (2016) reported that the effect of time and concentration of priming was significant on seed vigor and the most effective duration of priming was 12-hour priming. They also concluded that primed seeds have a more favorable germination vigor than non-primed seeds. Seed priming is considered as one of the strategies to improve the amount of chlorophyll a and b (Rehman and Ali, 2015). Furthermore, seed priming with SA has positively affected biochemical traits such as total chlorophyll (Singh et al., 2018).

Seed priming with the concentration of $0.1 \mathrm{mM}$ SA indicated the highest chlorophyll a, b and total chlorophyll content (Fig. 3.4.5) and higher carotenoid content was related to higher a concentration of SA $(1 \mathrm{mM})$ (Fig. 6$)$. The results are consistent with the results of (Yanik et al., 2018), who reported that the total chlorophyll content increased under 10 $\mu \mathrm{M}$ SA. Higher concentration of SA resulted in decreasing total chlorophyll and increasing carotenoid contents. Moharekar et al. (2003) indicated that different concentrations of SA can activate the synthesis of carotenoids and xanthophylls while a total chlorophyll content reduction occurs in wheat. It seems that decreasing chlorophyll content due to the SA-induced excess leads to the accumulation of ROS and the inhibition of plant growth and development. (Ma et al., 2013). However, the results of other studies 
indicated that the SA pretreatment leads to a significant increase in the chlorophyll and carotenoid content (Saidi et al., 2013), which is beneficial for improving photosynthesis (Zhang et al., 2015). Catalase is one of the most important antioxidant enzymes, which can be increased in plants using a seed priming technique (Fallah et al., 2018). The results of the present study indicated that treating seeds with $1 \mathrm{mM} \mathrm{SA}$ for 24 hours had the most significant effect on the activity of CAT and POD enzymes. Yang et al (2016) investigated that treating seeds with SA could enhance the defense mechanisms of Helianthus annuus, leading to an increase in germination indices by increasing the activity of antioxidant enzymes (Omid and Farzad, 2012).

\section{Conclusion}

The results indicated that the priming technique can improve the seed germination components of Catharanthus roseus. Furthermore, a significant difference was reported between different priming times. Additionally, seed priming time is regarded as one of the important factors in seed treatment and determining the appropriate priming time may prevent the negative effect of pretreatment on germination characteristics and seedling growth of primed seeds. In order to have a positive effect, the best time for pretreatment on improved germination and seedling growth indices should be determined for every plant. In the present study, the results indicated that an increase in the pre-treatment time results in improving most of the components related to germination. In this experiment, the most beneficial length of time was 24 hours for pre-treatment of Catharanthus roseus seeds. In addition, the best results were related to 0.5 and $1 \mathrm{mM}$ SA concentrations. Therefore, determining the best concentration and time for seed priming is considered as a key factor to implement seed priming effects in the most beneficial way.

\section{REFERENCES}

[1] Arnon, A. (1967): Method of extraction of chlorophyll in the plants. - Agronomy Journal, 23: $112-121$.

[2] Azarniya, M., Biabani, A., Eisvand. H. R., Gholamalipour Alamdar, E., Safikhani, S. (2016): Effect of seed priming with gibberellic acid and salicylic acid on germination characteristic and seed and seedlings physiological quality of lentil (lens culinaris 1.). Iranian Journal of Seed Research 3: 59-73.

[3] Baalbaki, R., Zurayk, R., Bleik, M., Talhouk, S. (1999): Germination and seedling development of drought tolerant and susceptible wheat under moisture stress. - Seed science and technology 27: 291-302.

[4] Baninasab, B. (2010): Induction of drought tolerance by salicylic acid in seedlings of cucumber (Cucumis sativus L.). - The Journal of Horticultural Science and Biotechnology 85: 191-196.

[5] Barkat, M. A., Abul, H., Rahman, M. A. (2017): Agricultural, pharmaceutical, and therapeutic interior of Catharanthus roseus (L.) G. Don. - Catharanthus roseus. Springer.

[6] Batool, A., Ziaf, K., Amjad, M. (2015): Effect of halo-priming on germination and vigor index of cabbage (Brassica oleracea var. capitata). - Journal of Environmental and Agricultural Sciences 2: 8pp.

[7] Bewley, J. D., Bradford, K. J., Hilhorst, H. W., Nonogaki, H. (2013): Germination. - Seeds. Springer.

[8] Brancalion, P., Novembre, A., Rodrigues, R., Tay, D. (2008): Priming of Mimosa bimucronata seeds-a tropical tree species from Brazil. - Acta Horticulturae 782: 163. 
[9] Chaoui, A., Mazhoudi, S., Ghorbal, M. H., El Ferjani, E. (1997): Cadmium and zinc induction of lipid peroxidation and effects on antioxidant enzyme activities in bean (Phaseolus vulgaris L.). - Plant Science 127: 139-147.

[10] Di Girolamo, G., Barbanti, L. (2012): Treatment conditions and biochemical processes influencing seed priming effectiveness. - Italian Journal of Agronomy 7: 25.

[11] Eastmond, P. J., Graham, I. A. (2001): Re-examining the role of the glyoxylate cycle in oilseeds. - Trends in plant science 6: 72-78.

[12] El-Esawi, M. A., Elansary, H. O., El-Shanhorey, N. A., Abdel-Hamid, A. M., Ali, H. M., Elshikh, M. S. (2017): Salicylic acid-regulated antioxidant mechanisms and gene expression enhance rosemary performance under saline conditions. - Frontiers in physiology 8: 716.

[13] Espanany, A., Fallah, S. (2016): Seed germination of dill (Anethum graveolens L.) in response to salicylic acid and halopriming under cadmium stress. - Iran J Plant Physiol. 6: 1702-1713.

[14] Fallah, S., Malekzadeh, S., Pessarakli, M. (2018): Seed priming improves seedling emergence and reduces oxidative stress in Nigella sativa under soil moisture stress. Journal of Plant Nutrition 41: 29-40.

[15] Farooq, M., Wahid, A., Kobayashi, N., Fujita, D., Basra, S. (2009): Plant drought stress: effects, mechanisms and management. - Sustainable agriculture. Springer.

[16] Foti, R., Abureni, K., Tigere, A., Gotosa, J., Gere, J. (2008): The efficacy of different seed priming osmotica on the establishment of maize (Zea mays L.) caryopses. - Journal of Arid Environments 72: 1127-1130.

[17] Gorzi, A., Omidi, H., Bostani, A. (2017): Morpho-physiological responses of stevia (stevia rebaudiana bertoni) to various priming treatments under drought stress. - Applied Ecology And Environmental Research 16: 4753-4771.

[18] Guan, L., Scandalios, J. G. (1995): Developmentally related responses of maize catalase genes to salicylic acid. - Proceedings of the National Academy of Sciences 92: 5930-5934.

[19] Gueta-Dahan, Y., Yaniv, Z., Zilinskas, B. A., Ben-Hayyim, G. (1997): Salt and oxidative stress: similar and specific responses and their relation to salt tolerance in citrus. - Planta 203: 460-469.

[20] Harris, D., Pathan, A., Gothkar, P., Joshi, A., Chivasa, W., Nyamudeza, P. (2001): On-farm seed priming: using participatory methods to revive and refine a key technology. Agricultural Systems 69: 151-164.

[21] Hu, J., Zhu, Z., Song, W., Wang, J., Hu, W. (2005): Effects of sand priming on germination and field performance in direct-sown rice (Oryza sativa L.). - Seed Science and Technology 33: 243-248.

[22] Huang, C., Wang, D., Sun, L., Wei, L. (2016): Effects of exogenous salicylic acid on the physiological characteristics of Dendrobium officinale under chilling stress. - Plant growth regulation 79: 199-208.

[23] Hunter, E., Glasbey, C., Naylor, R. (1984): The analysis of data from germination tests. The Journal of Agricultural Science 102: 207-213.

[24] Hussain, S., Zheng, M., Khan, F., Khaliq, A., Fahad, S., Peng, S., Huang, J., Cui, K., Nie, L. (2015): Benefits of rice seed priming are offset permanently by prolonged storage and the storage conditions. - Scientific reports 5: 8101.

[25] Hussein, H. J. (2015): Effect of seed priming treatment with salicylic acid on viability of okra (Abelmoschus esculentus L.) seeds. - Euphrates Journal of Agriculture Science 7(2): $1-9$.

[26] Kaya, M. D., Okçu, G., Atak, M., Cıkılı, Y., Kolsarıcı, Ö. (2006): Seed treatments to overcome salt and drought stress during germination in sunflower (Helianthus annuus L.). - European journal of agronomy 24: 291-295.

[27] Khan, A. A. (1992): Preplant physiological seed conditioning. - Horticultural reviews 13: $131-181$. 
[28] Khan, H., Ayub, C., Pervez, M., Bilal, R., Shahid, M., Ziaf, K. (2009): Effect of seed priming with $\mathrm{NaCl}$ on salinity tolerance of hot pepper (Capsicum annuum L.) at seedling stage. - Soil Environ 28: 81-87.

[29] Khoramdel, S., Rezvani Moghadam, P., Amin Ghafari, A., Shabahang J. (2012): Study the germination characteristics of black seed (nigella sativa 1.) under drought stress condition in different salicylic acid levels. - Iranian Journal of Field Crops Research 10: 709-725.

[30] Korkmaz, A. (2005): Inclusion of acetyl salicylic acid and methyl jasmonate into the priming solution improves low-temperature germination and emergence of sweet pepper. - HortScience 40: 197-200.

[31] Liopa-Tsakalidi, A., Kaspiris, G., Salahas, G., Barouchas, P. (2012): Effect of salicylic acid (SA) and gibberellic acid (GA3) pre-soaking on seed germination of stevia (Stevia rebaudiana) under salt stress. - Journal of Medicinal Plants Research 6: 416-423.

[32] Ma, C., Chhikara, S., Xing, B., Musante, C., White, J. C., Dhankher, O. P. (2013): Physiological and molecular response of Arabidopsis thaliana (L.) to nanoparticle cerium and indium oxide exposure. - ACS Sustainable Chemistry \& Engineering 1: 768-778.

[33] Maiti, R., Pramanik, K. (2013): Vegetable Seed Priming: a Low Cost, Simple and Powerful Techniques for Farmers' Livelihood. - International Journal of Bio-Resource \& Stress Management 4.

[34] Moharekar, S., Lokhande, S., Hara, T., Tanaka, R., Tanaka, A., Chavan, P. (2003): Effect of salicylic acid on chlorophyll and carotenoid contents of wheat and moong seedlings. Photosynthetica 41: 315.

[35] Mukherjee, S., Choudhuri, M. (1983): Implications of water stress-induced changes in the levels of endogenous ascorbic acid and hydrogen peroxide in Vigna seedlings. Physiologia Plantarum 58: 166-170.

[36] Murungu, F., Nyamugafata, P., Chiduza, C., Clark, L., Whalley, W. (2003): Effects of seed priming, aggregate size and soil matric potential on emergence of cotton (Gossypium hirsutum L.) and maize (Zea mays L.). - Soil and Tillage Research 74: 161-168.

[37] Muthulakshmi, S., Pandiyarajan, V. (2013): Influence of IAA on the vincristine content of Catharanthus roseus (L). G. Don. - Asian J Plant Sci Res 3: 81-87.

[38] Nejat, N., Valdiani, A., Cahill, D., Tan, Y.-H., Maziah, M., Abiri, R. (2015): Ornamental exterior versus therapeutic interior of Madagascar periwinkle (Catharanthus roseus): the two faces of a versatile herb. - The Scientific World Journal.

[39] Omid, A., Farzad, S.-Z. (2012): Osmo and hydro priming improvement germination characteristics and enzyme activity of Mountain Rye (Secale montanum) seeds under drought stress. - Journal of Stress Physiology \& Biochemistry 8.

[40] Omidbeigi, R. (2006): Production and processing of medicinal plants. - 4. Pub. Astane Ghodse Razaviee: 419.

[41] Pandey, S. (2017): Catharanthus roseus: Cultivation Under Stress Conditions. Catharanthus roseus. Springer.

[42] Panwar, P., Bhardwaj, S. (2005): Handbook of practical forestry, Agrobios (India).

[43] Paparella, S., Araújo, S., Rossi, G., Wijayasinghe, M., Carbonera, D., Balestrazzi, A. (2015): Seed priming: state of the art and new perspectives. - Plant cell reports 34: 12811293.

[44] Popova, L. P., Maslenkova, L. T., Yordanova, R. Y., Ivanova, A. P., Krantev, A. P., Szalai, G., Janda, T. (2009): Exogenous treatment with salicylic acid attenuates cadmium toxicity in pea seedlings. - Plant Physiology and Biochemistry 47: 224-231.

[45] Pouramir-Dashtmian, F., Khajeh-Hosseini, M., Esfahani, M. (2014): Improving chilling tolerance of rice seedling by seed priming with salicylic acid. - Archives of Agronomy and Soil Science 60: 1291-1302.

[46] Prabhu, D. S., Rajeswari, V. D. (2017): Catharanthus roseus: The Cancer-Fighting Medicine. - Catharanthus roseus. Springer.

[47] Ranal, M. A., Santana, D. G. D. (2006): How and why to measure the germination process? - Brazilian Journal of Botany 29: 1-11. 
[48] Ratikanta, K. (2011): Seed priming: an efficient farmers' technology to improve seedling vigour, seedling establishment and crop productivity. - Int J Bio-Resour Stress Manag 2: 297.

[49] Rehman, A., Ali, A. (2015): Priming with ascorbic acid, salicylic acid and hydrogen peroxide improves seedling growth of spring maize at suboptimal temperature. - Seedling 14: 2.5 .

[50] Rivas-San Vicente, M., Plasencia, J. (2011): Salicylic acid beyond defence: its role in plant growth and development. - Journal of experimental botany 62: 3321-3338.

[51] Rosental, L., Nonogaki, H., Fait, A. (2014): Activation and regulation of primary metabolism during seed germination. - Seed Science Research 24: 1-15.

[52] Saidi, I., Ayouni, M., Dhieb, A., Chtourou, Y., Chaïbi, W., Djebali, W. (2013): Oxidative damages induced by short-term exposure to cadmium in bean plants: protective role of salicylic acid. - South African journal of botany 85: 32-38.

[53] Santini, B. A., Martorell, C. (2013): Does retained-seed priming drive the evolution of serotiny in drylands? An assessment using the cactus Mammillaria hernandezii. American Journal of Botany 100: 365-373.

[54] Senbagalakshmi, P., Rao, M., Kumar, T. S. (2017): In vitro studies, biosynthesis of secondary metabolites and pharmacological utility of Catharanthus roseus (L.) G. Don.: a review. - Catharanthus roseus. Springer.

[55] Serraj, R., Sinclair, T. (2002): Osmolyte accumulation: can it really help increase crop yield under drought conditions? - Plant, cell \& environment 25: 333-341.

[56] Shah, J. (2003): The salicylic acid loop in plant defense. - Current opinion in plant biology 6: 365-371.

[57] Shahverdi, M. A., Omidi, H., Tabatabaei, S. J. (2017): Determination of optimum duration and concentration of Stevia (Stevia rebaudiana Bert.) seed priming with Boric acid $\left(\mathrm{H}_{3} \mathrm{BO}_{3}\right)$. - Türkiye Tarımsal Araştırmalar Dergisi 4: 24-30.

[58] Sharma, A., Rathore, S., Srinivasan, K., Tyagi, R. (2014): Comparison of various seed priming methods for seed germination, seedling vigour and fruit yield in okra (Abelmoschus esculentus L. Moench). - Scientia Horticulturae 165: 75-81.

[59] Shehab, G. G., Ahmed, O. K., El-Beltagi, H. S. (2010): Effects of various chemical agents for alleviation of drought stress in rice plants (Oryza sativa L.). - Notulae Botanicae Horti Agrobotanici Cluj-Napoca 38: 139-148.

[60] Singh, P., Singh, V., Singh, N., Pandurangam, V., Shahi, J. (2018): Ameliorating effect of seed priming by salicylic acid on biochemical traits in Rabi maize (Zea Mays L.) genotypes under normal and delayed sowing. - Journal of Pharmacognosy and Phytochemistry 7: 2923-2927.

[61] Siri, B., Vichitphan, K., Kaewnaree, P., Vichitphan, S., Klanrit, P. (2013): Improvement of quality, membrane integrity and antioxidant systems in sweet pepper ('Capsicum annuum'Linn.) seeds affected by osmopriming. - Australian Journal of Crop Science 7: 2068.

[62] Szalai, G., Horgosi, S., Soós, V., Majláth, I., Balázs, E., Janda, T. (2011): Salicylic acid treatment of pea seeds induces its de novo synthesis. - Journal of plant physiology 168: 213-219.

[63] Taha, H., El-Bahr, M., Seif-El-Nasr, M. (2009): In vitro studies on Egyptian Catharanthus roseus (L.) G. Don. IV: manipulation of some amino acids as precursors for enhanced of indole alkaloids production in suspension cultures. - Aust J Basic Appl. Sci. 3: 3137-3144.

[64] Varier, A., Vari, A. K., Dadlani, M. (2010): The subcellular basis of seed priming. Current Science: 450-456.

[65] Vazirimehr, M., Ganjali, H., Rigi, K., Keshtehgar, A. (2014): Effect of seed priming on quantitative traits corn. - Int. J Pl Sci. 4: 134-40.

[66] Verma, P., Mathur, A. K., Srivastava, A., Mathur, A. (2012): Emerging trends in research on spatial and temporal organization of terpenoid indole alkaloid pathway in Catharanthus roseus: a literature update. - Protoplasma 249: 255-268. 
[67] Yang, L., Wang, H., Zu, Y.-G., Zhao, C., Zhang, L., Chen, X., Zhang, Z. (2011): Ultrasound-assisted extraction of the three terpenoid indole alkaloids vindoline, catharanthine and vinblastine from Catharanthus roseus using ionic liquid aqueous solutions. - Chemical Engineering Journal 172: 705-712.

[68] Yanik, F., Aytürk, Ö., Çetinbaş-Genç, A., Vardar, F. (2018): Salicylic acid-induced germination, biochemical and developmental alterations in rye (Secale cereale L.). - Acta Botanica Croatica 77: 45-50.

[69] Zhang, Y., Xu, S., Yang, S., Chen, Y. (2015): Salicylic acid alleviates cadmium-induced inhibition of growth and photosynthesis through upregulating antioxidant defense system in two melon cultivars (Cucumis melo L.). - Protoplasma 252: 911-924. 